DOI: https://doi.org/10.24127/ajpm.v10i4.4227

\title{
EFEKTIVITAS MODEL PEMBELAJARAN KONSTEKSTUAL BERBASIS ETNOMATEMATIKA DITINJAU DARI KEMAMPUAN PEMAHAMAN KONSEP MATEMATIKA DAN SIKAP DISIPLIN
}

\author{
Maria Fatima Mei ${ }^{*}$, Stefania Baptis Seto ${ }^{2}$, Stefanus Notan Tupen ${ }^{3}$ \\ 1,2,3* Pendidikan Matematika, Universitas Flores, Ende, Indonesia \\ *Corresponding author. \\ E-mail: $\quad$ nonaima37@gmail.com ${ }^{1)}$ \\ stefaniseto6@gmail.com $^{2}$ \\ stefnotan@gmail.com ${ }^{3)}$
}

Received 15 September 2021; Received in revised form 17 Novermber 2021; Accepted 27 December 2021

\begin{abstract}
Abstrak
Rendahnya pemahaman konsep dan sikap disiplin disebabkan oleh kurangnya kreatifitas guru dalam mengaitkan pembelajaran dengan kehidupan sehari-hari. Tujuan dari penelitian ini adalah untuk mengetahui keefektifan dari model pembelajaran kontekstual berbasis etnomatematika terhadap kemampuan pemahaman konsep matematika dan sikap disiplin. Penelitian ini merupakan kuasi eksperimen dengan sampel penelitian 22 orang mahasiswa program studi Pendidikan matematika semester II Universitas Flores. Instrument yang digunakan pada penelitian ini adalah tes pemahaman konsep dan angket sikap disiplin mahasiswa. Teknik pengumpulan data dilakukan dengan menggunakan tes dan angket. Analisis data dilakukan secara deskriptif dan inferensial. Hasil penelitian menyimpulkan bahwa Pemahaman Konsep memperoleh nilai signifikan 0.000 hal tersebut berarti nilai $\mathrm{p}<0.005$ dan untuk sikap disiplin 0.003 hal tersebut berarti nilai $\mathrm{p}<0.005$, sehingga dapat diambil suatu keputusan bahwa Ho ditolak yang artinya terdapat perbedaan pre-test dan post-test Pemahaman konsep dan sikap disiplin mahasiswa sebelum dan sesudah penerapan pembelajaran kontekstual berbasis etnomatematika. Oleh karena itu, dapat disimpulkan bahwa mahasiswa semester II sesudah menerapkan model pembelajaran kontekstual berbasis etnomatematika hasil pemahaman konsep dan sikap disiplin lebih baik dari pada sebelum menggunakan pembelajaran dengan penerapan model pembelajaran kontekstual berbasis etnomatematika
\end{abstract}

Kata kunci: etnomatematika; kontekstual; pemahaman konsep; sikap disiplin

\begin{abstract}
The low understanding of concepts and discipline is caused by the lack of creativity of teachers in learning with everyday life. The purpose of this study was to determine the effectiveness of the ethnomathematics-based contextual learning model. This study is a quasi-experimental research sample of 22 students of the second semester Mathematics Education study program at the University of Flores. The instruments used in this study were a concept understanding test and a student discipline attitude questionnaire. Data collection techniques were carried out using tests and questionnaires. Data analysis was done descriptively and inferentially. The results of the study concluded that Concept Understanding obtained a significant value of 0.000 which means the p-value $<0.005$ and for disciplined attitude 0.003 it means the p-value <0.005, so a decision can be taken that Ho is rejected, which means that there are differences in the pre-test and post-test understanding. concepts and student discipline attitudes before and after the application of ethnomathematical-based contextual learning. Therefore, it can be concluded that second-semester students after applying the ethnomathematics-based contextual learning model the results of understanding concepts and discipline attitudes are better than before using the ethnomathematics-based contextual learning model.
\end{abstract}

Keywords: contextual; concept understanding; discipline; ethnomathematics

This is an open access article under the Creative Commons Attribution 4.0 International License 
DOI: https://doi.org/10.24127/ajpm.v10i4.4227

\section{PENDAHULUAN}

Pembelajaran kontekstual berbasis etnomatematika merupakan pembelajaran berbasisis budaya. Dimana pembelajaran matematika dikaitkan dengan budaya yang ada. Pengintegrasian kebudayaan tempat tinggal mahasiswa sebagai unsur kontekstual dalam pembelajaran, (Hardiani, Irawati, \& Maulana, 2017). Hal ini menunjukkan bahwa konsep matematika dapat dikontekstualkan,, (Wondo, Mei, \& Naja 2020). Marsigit et al., (2019) Etnomatematika merupakan suatu ilmu yang digunakan untuk memahami bagaimana matematika dapat penyusaian terhadap lingkungan dari sebuah budaya. Demikian juga Utari, (2015) menjelaskan etnomatematika merupakan cara khusus yang dipakai dalam aktivitas matematika. Sejalan dengan pendapat Budiarto, (2018) etnomatematika merupakan representasi dinamis dan kompleks yang menggambarkan pengaruh kultural.

Dalam pemahaman konsep tersebut dibutuhkan sikap disiplin pada proses pembelajaran. Disiplin adalah suatu sikap seseorang mematuhi, menerima ataupun mentaati segala norma (Yuliyanto, Fadriyah,Yeli, Wulandari, 2018). Hudaya, (2018) disiplin belajar dapat diartikan sebagai suatu pengendalian diri. Bagi orangorang yang berhasil dalam belajar dan berkarya disebabkan karena mereka selalu disiplin (Ardi, 2012). Nilai sikap displin pada mahasiswa tidak terlepas dari sumber daya, (Mei, Seto, \& Wondo 2020). Mawaddah \& Maryanti, (2016) Pemahaman konsep adalah kemampuan untuk menerangkan dan mengintegrasikan sesuatu. Menurut Mei, Seto, \& Wondo (2020) indikator kemampuan pemahaman konsep terdiri atas mengulang sebuah konsep, memberikan contoh berdasarkan fakta, menyajikan konsep dari berbagai bidang keilmuan matematika, memecahkan masalah berdasarkan konsep. Meskipun diberikan stimulus berkaitan dengan materi bangun datar namun, mereka belum bisa mengintegrasikan.

Penerapan pembelajaran dalam kelas selama ini masih menggunakan model kontekstual tetapi tidak berbasis etnomatematika. Hal tersebut menjadi masalah dalam memahami sebuah definisi pada geometri dasar. Hal ini sejalan dengan pemikiran Santoso (2017), mengatakan pembelajaran kontekstual adalah konsep belajar yang membantu pengajar mengaitkan antara materi yang diajarkan dengan situasi dunia nyata. Pembelajaran kontekstual merupakan suatu konsepsi yang membantu guru dalam mengaitkan materi pembelajaran dengan kehidupan sehari-hari (Suhartini, Edi, \& Edy 2016).

Berdasarkan hasil observasi, sebagian besar mahasiswa mengalami kendala, diantaranya ditemukan mahasiswa kurang memahami konsep geometri, menguasai materi-materi prasyarat dengan baik, dan kurang memiliki kemampuan nalar yang logis dalam menyelesaikan soal-soal matematika.

Tujuan dari penelitian ini sebagai solusi untuk mengetahui keefektifan dari model pembelajaran kontekstual berbasis etnomatematika terhadap kemampuan pemahaman konsep dan sikap disiplin pada mahasiswa semester II pada program studi Pendidikan matematika universitas Flores

\section{METODE PENELITIAN}

Jenis penelitian ini adalah penelitian kuasi eksperimen menggunakan pendekatan kuantitatif dengan perlakuan berupa kontekstual berbasis etnomatematika. Populasi penelitian 
mahasiswa semester 2 Program Studi Pendidikan Matematika Universitas Flores, karena terdapat satu kelas maka kelas tersebut dijadikan sampel sebagai kelas eksperimen sebanyak 22 orang.

Prosedur yang dilakukan dalam penelitian ini adalah: 1) menyusun instrumen penelitian (tes hasil belajar, angket pemahaman konsep, dan sikap disiplin) dan perangkat pembelajaran (Rencana Pembelajaran Semester (RPS) dan Lembar Kegiatan Mahasiswa (LKM), 2) Validasi oleh ahli dengan menggunakan validitas isi yang digunakan pada tes hasil belajar (THB) dan untuk instrument angket sikap disiplin menggunakan validitas isi dan konstruk, 3) estimasi reliabilitas instrumen penelitian , 4) melakukan revisi instrumen penelitian, 5) memberikan angket sikap disiplin dan kemampuan pemahaman konsep kepada mahasiswa untuk diisi sebelum dilakukan pretestt, 6) melakukan pretest hasil belajar sebelum diberikan perlakuan, 7) memberikan perlakuan yang telah direncanakan, 8) memberikan angket sikap disiplin dan kemampuan pemahaman konsep kepada mahasiswa setelah diberikan perlakuan tetapi sebelum postest, 9) melakukan postest hasil belajar setelah diberikan perlakuan.

Teknik pengumpulan data dilakukan dengan menggunakan angket dan tes. Instrumen pengumpulan data dalam penelitian ini adalah instrumen tes hasil belajar dan angket sikap disiplin dan kemampuan pemahaman konsep. Setelah instrumen tes dan angket disusun, kemudian divalidasi oleh ahli berdasarkan kesesuaian antara itemitem pertanyaan dengan indikator masing-masing instrumen (validitas isi). Instrumen yang telah divalidasi selanjutnya dilakukan uji coba untuk mengestimasi koefisien reliabilitas dan bukti validitas konstruk.

Analisis data dilakukan secara deskriptif dan inferensial.

Data yang dideskripsikan merupakan data yang diperoleh dari pengukuran hasil belajar dan sikap disiplin dan kemampuan pemahaman konsep. Analisis statistik inferensial dilakukan dalam beberapa tahap diantaranya: 1) melakukan uji normalitas (sebelum dan sesudah perlakuan), 2) melakukan uji homogenitas (sebelum dan sesudah perlakuan), 3) uji keefektifan ditinjau kemampuan pemahaman konsep dan sikap disiplin dengan analisis paired sample t-test. Analisis tersebut melihat keadaan perbedaan rata-rata sebelum dan sesudah perlakuan (Ismawati \& Prasetyo 2020).

\section{HASIL DAN PEMBAHASAN}

Perangkat pembelajaran yang telah disusun divalidasi dan oleh dua orang validator yaitu ibu Sofia Sa'o dan Bapak Gregorius Taga. untuk perangkat pembelajaran RPS dan LKM dan Untuk validasi angket sikap disiplin menggunakan SPSS dan dapat dilihat pada Tabel 1.

Tabel 1. Skor dan Analisis Validasi RPS dan LKM

\begin{tabular}{ccc}
\hline \multirow{2}{*}{ Validator } & \multicolumn{2}{c}{ A } \\
\cline { 2 - 3 } & RPS & LKM \\
\hline 1 & 159 & 89 \\
2 & 148 & 90 \\
Skor tiap Aspek & 153,5 & 89,5 \\
Skor Perangkat & \multicolumn{2}{c}{243} \\
\hline
\end{tabular}

Data Tabel 1 menunjukkan bahwa hasil validasi dari dua orang ahli yaitu ibu Sofia Sa'o dan Bapak Gregorius Taga yang memenuhi kriteria sangat valid. Berdasarkan tabel 1, dapat disimpulkan bahwa analisis validasi 
DOI: https://doi.org/10.24127/ajpm.v10i4.4227

perangkat pembelajaran baik pada komponen RPS dan LKM dan komponen total masing-masing memenuhi kategori sangat valid. Hasil penilaian ini menunjukkan bahwa perangkat pembelajaran dapat digunakan.

Hasil uji menunjukan bahwa keseluruhan item instrument yang dikembangkan dengan 40 item valid dengan tingkat rata-rata koefisien 0,835 $>0,30$ Hasil tersebut menunjukkan bahwa instrument dapat digunakan pada kelas ekperimen

Untuk reliabilitas angket sikap diperoleh nilai alpha 0,829 sedangkan untuk butir soalnya memiliki nilai alpha 0,855 . Jadi kriteria validitas dan reliabitas maka perangkat pembelajaran dan angket sikap disiplin dapat digunakan.

Pada proses penerapan langkahlangkah yang harus dilakukan oleh mahasiswa yaitu pertama mahasiswa wajib menguasai materi geometri; kedua mahasiswa mencari bagianbagian dari rumah yang berkaitan dengan geometri; ketiga mahasiswa dapat menyelesaikan masalah yang berkaitan geometri dengan menggunakan rumus-rumus geometri.

Setelah perangkat dikatakan valid dan reliabel maka dilakukan uji asumsi yaitu normalitas dan homogenitas. Untuk hasil normalitas dapat dilihat pada Tabel 2.

Tabel 2. Hasil Uji Normalitas Pre-test dan Post Test

\begin{tabular}{llc}
\hline No & Data & Nilai. Sig \\
\hline 1 & Pre-Test Pemahaman Konsep & 0,525 \\
2 & Pre-Test Sikap Disiplin & 0,204 \\
3 & Post-Test Pemahaman Konsep & 0,383 \\
4 & Post-Test Sikap Disiplin & 0,159 \\
\hline
\end{tabular}

Pada Tabel 2 menunujukkan bahwa nilai nilai $p>0.05$ berdistribusi normal. sehingga dapat dinyatakan Ho diterima yang artinya data sampel dari populasi yang berdistribusi normal. Setelah syarat uji normalitas terpenuhi, langkah selanjutnya dilakukan uji homogenitas yang analisisnya menggunakan SPSS 20.0. Hasil uji homogenitas pre-test dan post-test pemahaman konsep dan sikap disiplin dapat dilihat pada Tabel 3 .

Tabel 3. Hasil Uji Homogenitas

\begin{tabular}{llc}
\hline No & \multicolumn{1}{c}{ Data } & Nilai sig. \\
\hline 1 & Pemahaman Konsep & 0,27 \\
2 & Sikap Disiplin & 0,327 \\
\hline
\end{tabular}

Pada Tabel 3 menunjukan bahwa nilai signifikan berdasarkan hasil pretest dan post-test yang diperoleh untuk pemahaman konsep adalah $p>0.05$ yaitu $0,271>0.05$, untuk sikap disiplin diperoleh $p>0.05$ yaitu $0.372>0.05$, sehingga dapat dinyatakan bahwa $\mathrm{H}_{0}$ diterima yang artinya data sampel homogen.

Setelah uji normalitas dan uji homogenitas telah memenuhi syarat, langkah selanjutnya paired sample t-test berpasangan yang dianalisis dengan menggunakan aplikasi SPSS 20.0. Hasil paired sample t-test pre-test dan posttest pemahaman konsep dan sikap disiplin terlihat seperti pada Tabel 4 . 
DOI: https://doi.org/10.24127/ajpm.v10i4.4227

Tabel 4 Hasil Analisis paired sample t-test

\begin{tabular}{llll}
\hline Kondisi & $t_{\text {hitung }}$ & $d f$ & Sig \\
\hline Pemahaman Konsep & 10,851 & 21 & 0,000 \\
Sikap Disiplin & 3,339 & 21 & 0,003 \\
\hline
\end{tabular}

Tabel 4 diperoleh informasi bahwa hasil paired sample t-test pada Pemahaman Konsep dan Sikap Disiplin didapatkan bahwa $p$ (2-tailed) $<0.05$, sehingga dapat diambil suatu keputusan bahwa Ho ditolak yang artinya terdapat perbedaan pre-test dan post-test Pemahaman konsep dan sikap disiplin mahasiswa sebelum dan sesudah penerapan perangkat pembelajaran kontekstual berbasis etnomatematika. Oleh karena itu, dapat disimpulkan bahwa mahasiswa semester II sesudah menerapkan model pembelajaran kontekstual berbasis etnomatematika hasil pemahaman konsep dan sikap disiplin lebih baik dari pada sebelum menggunakan pembelajaran dengan pengembangan model pembelajaran kontekstual berbasis etnomatematika. Selain itu yang menjadi kelebihan pada penelitian ini yaitu mahasiswa dapat mengaitkan matematika dengan budaya dalam kehidupan sehari-hari dan bisa menyelesaikan masalah berkaitan budaya serta mengenalkan budaya yang dimiliki kepada masyarakat.

Penelitian ini sejalan dengan hasil penelitian Isharyadi (2018) yang menyatakan bahwa adanya pengaruh pendekatan kontekstual terhadap kemampuan pemecahan masalah matematis. Hal ini juga disetujui dengan penelitiannya Dosinaeng et al., (2020) yang menyatakan bahwa eksplorasi etnomatematika geometri dapat digunakan oleh para guru matematika untuk mengembangkan pembelajaran geometri di kelas. Pembelajaran kontekstual berbasis etnomatematika juga dapat meningkatkan motivasi belajar matematika siswa (Ramopoly
2020). Hasil kajian dalam penelitian Samijo \& Yohanie, (2017) diperoleh bahwa pada motif Riwog, goyor dan motif Obar Abir dapat digunakan untuk menjelaskan konsep geometri transformasi seperti konsep translasi dan refleksi serta penggunaan prinsip pengubinan pada satu jenis bangun geometri teselasi yaitu persegi. Dari hasil penelitian-penelitian tersebut di temukan bahwa pembelajaran kontekstual berbasis etnomatematika siswa dapat berinteraksi dengan baik dan dapat menemukan konsep-konsep yang terdapat pada bangun dan motif bernuasa budaya.

Dalam penelitian ini mahasiswa merasa senang dapat belajar diluar kelass dengan situasi berbeda sehingga mereka dengan leluasa dapat meningkatkan pemahaman konsep dengan apa yang mereka lihat dan mereka rasakan. Dilapangan juga mahasiswa dapat bertanya jawab dan mengetahui apa yang tidak mereka ketahui. Hal ini sejalan dengan penelitian (Kusuma 2019) Hasil penelitian memperlihatkan bahwa terdapat perbedaan kemampuan komunikasi matematis antara siswa yang memperoleh pembelajaran kontekstual berbasis etnomatematika dengan penerapan Mozart effect (PEM) dengan siswa yang memperoleh pembelajaran langsung (PL), dan siswa bersikap positif terhadap pembelajaran kontekstual berbasis etnomatematika dengan penerapan Mozart effect. 


\section{KESIMPULAN DAN SARAN}

Berdasarkan hasil penelitian yang diperoleh bahwa setelah penerapan pembelajaran kontekstual berbasis etnomatematika terjadi peningkatan kemampuan pemahaman konsep dan sikap disiplin yang signifikan. Dengan demikian penerapan pembelajaran kontekstual berbasis etnomatematika efektif untuk digunakan dalam pembelajaran geometri.

Adapun saran diberikan bagi guru atau dosen dalam menerapkan pembelajaran kontekstual berbasis etnomatematika hendaknya lebih memberikan banyak waktu untuk berdiskusi atau umpan balik kepada siswa atau mahasiswa. Bagi peneliti lanjutan agar dapat menerapkan pembelajaran kontekstual berbasis etnomatematika pada materi lain.

\section{DAFTAR PUSTAKA}

Ardi, M. (2012). Pengaruh Pemberian Hukuman Terhadap Disiplin Siswa Dalam Belajar. Jurnal Eksos 8(1):61-72.

Budiarto, M. T. (2018). EtnoMatematika: Optimalisasi Berpikir Matematis Di Era Milenial. in Babak final OLMAT UINSA 2018, Himpunan Mahasiswa PMT, Surabaya. Surabaya.

Dosinaeng, W. B. N., Lakapu, M.,Jagom, Y. O.,Uskono, V. I.,Leton, S. I., \& Djong, K. D. (2020). Etnomatematika Untuk Siswa Sekolah Menengah:Eksplorasi KonsepKonsep Geometri Pada Budaya Suku Boti." AKSIOMA: Jurnal Program Studi Pendidikan Matematika 9(3):739. doi: 10.24127/ajpm.v9i3.2900.

Hardiani, D., Irawati, R., \& Maulana, M. (2017). Penerapan Pendekatan Kontekstual Berbasis Etnografi
Majalaya Untuk Meningkatkan Kemampuan Pemecahan Masalah Matematis Siswa Pada Materi Penjumlahan Dan Pengurangan Bilangan Bulat. Jurnal Pena Ilmiah 2(1):981-90. doi: 10.17509/jpi.v2i1.11245.

Hudaya, A. (2018). Pengaruh Gadget Terhadap Sikap Disiplin Dan Minat Belajar Peserta Didik. Research and Development Journal of Education 4(2):86-97. doi: 10.30998/rdje.v4i2.3380.

Isharyadi, R. (2018). Pengaruh Penerapan Pendekatan Kontekstual Terhadap Peningkatan Kemampuan Pemecahan Masalah Matematis Siswa. AKSIOMA: Jurnal Program Studi Pendidikan Matematika 7(1):48. doi: 10.24127/ajpm.v7i1.1342.

Ismawati, D., \& Prasetyo, I. (2020). Efektivitas Pembelajaran Menggunakan Video Zoom Cloud Meeting Pada Anak Usia Dini Era Pandemi Covid-19. Jurnal Obsesi : Jurnal Pendidikan Anak Usia Dini 5(1):665. doi: 10.31004/obsesi.v5i1.671.

Kusuma, D. A. (2019). Peningkatan Komunikasi Matematis Siswa Menggunakan Pembelajaran Kontekstual Berbasis Etnomatematika Dengan Penerapan Mozart Effect (Studi Eksperimen Terhadap Siswa Sekolah Menengah Pertama). TEOREMA : Teori Dan Riset Matematika 4(1):65. doi: 10.25157/teorema.v4i1.1954.

Marsigit, Nila, M. M., \& Riskianto, I. (2019). Pengembangan Perangkat Pembelajaran Etnomatematika Untuk Meningkatkan Kompetensi Mahasiswa Pendidikan Matematika. Jurdikmat 1:105-12. 
Mawaddah, S., \& Maryanti, R. (2016).

Kemampuan Pemahaman Konsep

Matematis Siswa SMP Dalam

Pembelajaran Menggunakan

Model Penemuan Terbimbing

(Discovery Learning). EDU-MAT:

Jurnal Pendidikan Matematika 4(1):76-85.

Mei, M. F., Seto, S. B., \& Wondo, M.

T. S. (2020). Pembelajaran

Kontekstual Melalui Permainan

Kelereng Pada Siswa Kelas Iii Sd

Untuk Meningkatkan Pemahaman

Konsep Perkalian. Jupika: Jurnal

Pendidikan Matematika 3(2):61-

70. doi: 10.37478/jupika.v3i2.669.

Ramopoly, I. H. (2020). Meningkatkan

Motivasi Belajar Matematika

Siswa Kelas V SDN 2 Rantepao

Dengan Menerapkan Pembelajaran

Kontekstual

Berbasis

Etnomatematika Suku Toraja.

Elementary Journal 3(1):14-22.

Samijo, S. Y., \& Dian, D. (2017).

Pengaruh Model Pembelajaran

Kontekstual Berbasis

Etnomatematika Pada Pola Batik

Tenun (ATBM) Khas Kota Kediri

Terhadap Kemampuan Refleksi

Dan Simetri Mahasiswa Semester

2 Prodi Pendidikan Matematika UNP Kediri. Jurnal Math Educator Nusantara: Wahana Publikasi Karya Tulis Ilmiah Di Bidang Pendidikan Matematika 3(2):135. doi: 10.29407/jmen.v3i2.11975.
Santoso, E. (2017). Penggunaan Model Pembelajaran Kontekstual Untuk Meningkatkan Kemampuan Pemahaman Matematika Siswa Sekolah Dasar. Jurnal Cakrawala Pendas 3(1):16-29. doi: 10.31949/jcp.v3i1.407.

Suhartini, I., Edi, S. \& Edy, S. (2016). Pengaruh Pembelajaran Kontekstual Terhadap Kemampuan Pemecahan Masalah Matematik Dan Kemandirian Belajar Siswa Di MTS Miftahussalam Medan. Paradikma 9(3):62-71.

Utari, T. (2015). Keefektifan Model Pembelajaran Probing - Prompting Berbasis Etnomatematika Untuk Meningkatkan Kemampuan Komunikasi Matematis. Skripsi: Universitas Negeri Semarang.

Wondo, M.T. S., Mei, M. F., \& Naja, F. Y. (2020). Exploration of Geometry Symbol in Traditional Houses of the Lio District of Ende for Geometry Learning. Jurnal Pendidikan Dan Kebudayaan Missio 12(1):32-44. doi: 10.36928/jpkm.v12i1.71.

Yuliyanto, Fadriyah, A., Yeli, A., Wulandari, K. P., \&. Hayani. (2018). Pendekatan Saintifik Untuk Mengembangkan Karakter Disiplin Dan Tanggung Jawab Siswa Sekolah Dasar. Metodik Didaktik 13(2):87-98. doi: 10.17509/md.v13i2.9307. 